\title{
Imaginary economies: the case of the 3D printer
}

\author{
Jens Schröter ${ }^{1}$ (iD \\ Published online: 8 May 2020 \\ (C) The Author(s) 2020
}

\begin{abstract}
In the call for the special issue for the EAEPE Journal, we can find the word "scenario." The question is if the authors can imagine scenarios in which "potential strategies for the appropriation of existing capitalist infrastructures [...] in order to provoke the emergence of post-capitalist infrastructures" can be described. Obviously, the call verges on the border of science fiction - and this is not a bad thing. Diverse strands of media studies and science and technology studies have shown (e.g., Schröter 2004; Kirby 2010; Jasanoff and Kim 2015; McNeil et al. 2017) that not only the development of science and (media) technology is deeply interwoven in social imaginaries about possible outcomes and their implicated futures, but there is a whole theoretical tradition in which societies as such are fundamentally constituted by imaginary relations (Castoriadis 1975/2005). But in all these discussions, one notion very seldom appears: that of an "imaginary economy," meaning a collectively held system of more or less vague or detailed ideas, what an economy is, how it works, and how it should be (especially in the future; but see the somewhat different usage recently in Fabbri 2018). The aim of the paper is to outline a notion of "imaginary economy" and its necessary functions in the stabilization of a given economy, but even more so in the transformation to another economy - how should a transformation take place if there's not at least a vague image where to go? Of course, we could also imagine a blind evolutionary process without any imaginary process but that seems not to be the way in which human societies - and economies - work. Obviously a gigantic research field opens up - so in the proposed paper, only one type of "imaginary economy" can be analyzed: It is the field that formed recently around the proposed usages and functions of $3 \mathrm{D}$ printing. In publications as diverse as Eversmann (2014) and Rifkin (2014), the 3D printer operates as a technology that seems to open up a post-capitalist future - and thereby it is directly connected to the highly imaginary "replicator" from Star Trek. In these scenarios, a localized omnipotent production-a post-scarcity scenario (see Panayotakis 2011) — overcomes by itself capitalism: But symptomatically enough, questions of work, environment, and planetary computation are (mostly) absent from these scenarios. Who owns the templates for producing goods with $3 \mathrm{D}$ printers? What
\end{abstract}

Jens Schröter

schroeter@uni-bonn.de

Extended author information available on the last page of the article 
about the energy supply? In a critical and symptomatic reading, this imaginary economy, very present in a plethora of discourses nowadays, is deconstructed and possible implications for a post-capitalist construction are discussed.

Keywords Imaginary $\cdot$ Science fiction $\cdot$ Discourse analysis $\cdot 3 \mathrm{D}$ printing

JEL codes $\mathrm{B} 59 \cdot \mathrm{O} 33 \cdot \mathrm{O} 36 \cdot \mathrm{P} 48 \cdot \mathrm{Y} 80 \cdot \mathrm{Z} 19$

\section{Introduction}

In the call for this special issue for the EAEPE Journal, we can find the word "scenario." The question is if the authors can imagine scenarios in which "potential strategies for the appropriation of existing capitalist infrastructures [...] in order to provoke the emergence of post-capitalist infrastructures" can be described. Obviously, the call verges on the border of science fiction - and this is not a bad thing. Diverse strands of media studies and science and technology studies ${ }^{1}$ have shown that not only the development of science and (media) technology is deeply interwoven in social imaginaries about possible outcomes and their implicated futures, but there is a whole theoretical tradition in which societies as such are fundamentally constituted by imaginary relations. ${ }^{2}$ But in all these discussions, one notion very seldom appears: that of an "imaginary economy," meaning a collectively held system of more or less vague or detailed ideas, what an economy is, how it works, and how it should be. ${ }^{3}$

Obviously a gigantic research field opens up (think alone of the traces of imaginary economics in science fiction ${ }^{4}$ ) — so in the proposed paper only, one type of "imaginary economy" can be analyzed: It is the field that formed recently around the proposed usages and functions of $3 \mathrm{D}$ printing. In diverse publications, ${ }^{5}$ the $3 \mathrm{D}$ printer operates as a technology that seems to open up a post-capitalist future - and thereby it is directly connected to the highly imaginary "replicator" from Star Trek. In these scenarios, a localized omnipotent production - a post-scarcity scenario-overcomes by itself capitalism: But symptomatically enough, questions of work, environment, and planetary

\footnotetext{
${ }^{1}$ Cf. Schröter (2004); Kirby (2010); Jasanoff and Kim (2015); McNeil et al. (2017).

${ }^{2}$ Cf. Castoriadis (1990).

${ }^{3}$ Especially in the future; but see the somewhat different usage in Fabbri (2018). Jessop (2013) has developed a very similar notion of "economic imaginaries," which he defines (p. 236) as a "semiotic ensemble that frames individual subjects' lived experience of an inordinately complex world and/or guides collective calculation about that world." He argues that "totality of economic activities is so unstructured and complex, it cannot be an object of effective calculation, management, governance, or guidance. Such practices are always oriented to 'imagined economies'." Therefore: "Economic imaginaries have a crucial constitutive role here in so far as they identify, privilege and seek to stabilize some economic activities from the totality of economic relations. They give meaning and shape thereby to the 'economic' field but are always selectively defined." He makes a detailed analysis of the imaginaries that accompanied the crisis after 2008. Theoretically, I completely agree with Jessop, the main difference is that he does not read popular discourses, like, e.g., science fiction, although their popularity heightens the relevance of the imaginaries produced there. Jessop bases his argument on the interesting study of Taylor (2004), see there especially chapter 5 on the economy as modern social imaginary.

${ }^{4}$ Cf. Davies (2018) and Schlemm (2019). See also the interesting website on "Economic Science Fiction \& Fantasy": http:/www.economicsff.com/.

${ }^{5}$ For example, Eversmann (2014) and Rifkin (2014).
} 
computation are (mostly) absent from these scenarios. Who owns the templates for producing goods with $3 \mathrm{D}$ printers? What about the energy supply? In a critical and symptomatic reading, this imaginary economy, very present in a plethora of discourses nowadays, is deconstructed and possible implications for a post-capitalist construction are discussed.

\section{3D printing and the replicator}

In 2014, Ludger Eversmann publishes the tome Projekt Post-Kapitalismus. Blueprint für die nächste Gesellschaft. ${ }^{6}$ The foreword already says:

Ludger Eversmann dares again to present a utopia. In return, he goes a long way and tells the story of a new industrial revolution that has already begun. The 3D printers and digital fabrication not only reveal a new mode of production, but also a new society that could leave capitalism behind. The utopia is guided by the goal of a universal manufacturing machine based on nanotechnology. So how would it be if the factories became so small that they fit into the cellar of every home, on the kitchen table or on the desk? Or standing in a small shop around the corner? Or in a bigger one, on the outskirts of town? That would change something, then everyone could own their own little factory, and this factory in their own cellar does all the things a person needs in life. At least as many as possible, and in the beginning certainly only a few, which you might not need at all. ${ }^{7}$

The 3D printer appears here in a narrative that deals with the overcoming of capitalism - apparently made possible by specific technical devices — although it is still unclear how this should take place. Elsewhere, Eversmann notes that

[i]n these hectic times of overproduction, with congested and overloaded transport channels around the world, where semi-finished and finished products and materials and raw materials have to be constantly transported back and forth halfway around the world, [...] the ideal manufacturing machine would obviously be used directly at the place of consumption and would be able to produce literally EVERYTHING - or at least much more of everything than, for example, an additive manufacturing 3D printer that cannot, for example, produce any electronics or even entire objects with complete functionality, a coffee machine for example. And which, of course, could also do this in economically justifiable working hours, with justifiable energy expenditure and in satisfactory quality; in other words, actually and literally (if possible) everything: from toothbrush to toothpaste to wool sweater and running shoes, from bicycle to kitchen toaster to mobile telephone and to a cup of tea, Earl Gray. ${ }^{8}$

\footnotetext{
${ }^{6}$ Cf. Eversmann (2014).

${ }^{7}$ Ibid., foreword.

${ }^{8}$ Ibid., Position 1449, misspelling of "Earl Grey" in the original text.
} 
Apparently, an "ideal fabrication machine" is imagined that is supposed to be able to produce anything - up to a cup of Earl Grey, after all. Why Earl Grey? Because Earl Grey is the favorite tea of the fictitious spaceship captain Captain Jean-Luc Picard from the science fiction television series Star Trek - The Next Generation, who repeatedly makes such a tea with the "replicator," a machine that can make any material object on demand. ${ }^{9}$ This replicator, so my argument, is the imaginary model ${ }^{10}$ in the discourses on $3 \mathrm{D}$ printing, the distant ultimate goal of an "ideal manufacturing machine," as whose appearance today's rather crude 3D printers operate. And with the "ideal fabrication machine," capitalism somehow stumbles - as it already does in Star Trek, since it is repeatedly noticed that in this fictitious future of mankind there is no money needed and that the economy functions somehow differently-even if this is not explained in detail. ${ }^{11}$ The configuration of the imaginary replicator as a model of $3 \mathrm{D}$ printing and a post-capitalist world can also be found elsewhere.

Jeremy Rifkin is an American economist who published a book in 2014 entitled The Zero Marginal Cost Society. The Internet of Things, The Collaborative Commons and the Eclipse of Capitalism. The title alone makes it clear that certain technological developments seem to lead to social change (or are co-evolutionary with certain social changes), which in turn ultimately lead to the overcoming of capitalism. Here, too, 3D printing plays a major role; there is a separate chapter on this topic in which Rifkin euphorically presents the small and large advances in the development of $3 \mathrm{D}$ printing and occasionally derives somewhat bold conclusions from them. He writes: "Like the replicator in the Star Trek television series, the printer can be programmed to produce an infinite variety of products." 12 The equation of 3D printers with the possibilities of the replicator in Star Trek (Eversmann knows the difference) is a strong exaggeration of the potentials of today's 3D printers. But Rifkin's statement seems correct: a reproduction via markets and thus money would not only be unnecessary, but in the long run perhaps also impossible, if such machines existed:

The new 3D printing revolution is an example of 'extreme productivity.' It is not fully here yet, but as it kicks in, it will eventually and inevitably reduce marginal costs to near zero, eliminate profit, and make property exchange in markets unnecessary for many (though not all) products. ${ }^{13}$

\footnotetext{
${ }^{9}$ Extensive fan knowledge about the replicator can be found under Memory Alpha (no year).

${ }^{10}$ In the sense of the so-called Leitbild sociology, cf. Dierkes et al. (1992).

${ }^{11}$ A particularly well-known scene in this respect can be found in the eighth Star Trek movie (Star Trek: First Contact (US Star Trek 1996b); it is so well-known that it can be found separately on YouTube, cf. Star Trek (1996a). Also very amusing is the episode 1:26 of Star Trek - The Next Generation (Star Trek 1988), in which the Enterprise awakens a broker who has been in artificial deep sleep for centuries, who then worries a lot about his fortune and can hardly understand that there is no money any more. On the imaginary economics in Star Trek, see in detail Saadia (2016) and especially ch. 3 on the replicator. There is a similar idea like the replicator in earlier science fiction, originally published in 1945, see the reissue O'Smith (1975). This is a short story on a replicator-like machine that severly disrupts the diegetic, capitalist economy.

12 Rifkin (2014), p. 75.

${ }^{13}$ Ibid., p. 78. There are of course alternative approaches to technological change and profits, e.g., Christensen and Raynor (2003) that would come to different conclusions. But the question here is less if Rifkin is 'correct' but that he's one representative for a wider discourse which imagines a post-scarcity economy in connection with $3 \mathrm{D}$ printing.
} 
I will come back to this question of the connection between a decentralized localized production and the alleged disappearance (or more actively: the overcoming) of capitalism. In any case, Star Trek has two more appearances. Rifkin remarks:

Three-dimensional printing, like so many inventions, was inspired by sciencefiction writers. A generation of geeks sat enthralled in front of their TV screens, watching episodes of Star Trek. In long journeys through the universe, the crew needed to be able to repair and replace parts of the spaceship and keep stocked with everything from machine parts to pharmaceutical products. The replicator was programmed to rearrange subatomic particles that are ubiquitous in the universe into objects, including food and water. The deeper significance of the replicator is that it does away with scarcity itself. ${ }^{14}$

And finally, he refers to one of the pioneers of 3D printer development, Neil Gershenfeld: "The idea, says Gershenfeld, is to provide the tools and materials anyone would need to build whatever they can envision. His ultimate goal 'is to create a Star Trek-style replicator in 20 years." 15

These examples should suffice: It becomes clear that the replicator from Star Trek is the imaginary model of $3 \mathrm{D}$ printing, at least when $3 \mathrm{D}$ printing is discursively associated with overcoming capitalism. This finding will now be discussed in two steps: Section 3 will reconstruct how and why the "ideal manufacturing machine" could actually come into conflict with capitalism - and what this assumption implies with regard to the relationship between a new technology and a given society. This leads to the question raised in Section 4 about the role of the imaginary-for the constantly invoked replicator as "ideal fabrication machine" is undoubtedly imaginary. However, this imaginary has a history that is not only present in the discourse on $3 \mathrm{D}$ printers, but also has a definable function there.

\section{Why could the "ideal manufacturing machine" be a problem for capitalism?}

How can the form of capitalism be described? A clarification of this question is necessary to understand why the "ideal fabrication machine" can be seen as a problem for capitalism. In the following, the answer will be simplified: neither exchange value vs. use value or surplus value production nor the question of the connection between productivity increase and labor, nor that of market and state, nor the immanent and external crises of this economic order, which is first and foremost the reason to think about its overcoming, can be discussed here. ${ }^{16}$ With Marx, ${ }^{17}$ however, it can be emphasized that a decisive form of capitalism is separate private production. Individual persons or individual companies produce and then see if they can sell

\footnotetext{
${ }^{14}$ Rifkin (2014), p. 78.

15 Ibid., p. 79. Sutherland (1966) unfolds another vision of an ideal manufacturing machine, because he envisions an 'ultimate display', in which 'the computer can control the existence of matter'.

${ }^{16}$ On various descriptions of capitalism see also Ingham (2008) and Hodgson (2015).

${ }^{17}$ Cf. Marx (1990), p. 132: "Only the products of mutually independent acts of labour, performed in isolation, can confront each other as commodities."
} 
their goods on the market. It is an ex post mediation between the producers. The argument of conventional economic theory (and common sense) is that an exchange in kind without money is a terribly awkward affair (the baker wants to exchange bread for meat with the butcher, but the butcher prefers pasta, etc.). Therefore, there would be money. The suppliers compete against each other and thus productivity is increased, as each supplier tries to push the others out of the market with cheaper products. This conception projects the form of separate private production ahistorically into the past. ${ }^{18}$ One can basically imagine three ways of overcoming this economic order, which has a beginning and thus presumably also an end ${ }^{19}$ :

(a) There are ways in which the exchange works effectively even without money (and its unpleasant side effects), e.g., by transferring the relevant information otherwise. This seems to be the core of the concept of a post-monetary economy based on digital matching proposed by Ralph and especially Stefan Heidenreich. ${ }^{20}$ However, it would be worth discussing whether a digitally facilitated exchange (without money) is not still capitalism (but after all, abstract wealth can no longer be accumulated). This approach is not discussed further here.

(b) One replaces the ex post with an ex ante mediation, i.e., not everyone produces separately from each other and then one sees what can be sold on the market, ${ }^{21}$ but the members of a society agree beforehand what they need and want, in order to produce and distribute the resulting goods. They switch to ex ante mediation. This opens up the whole terrain of planned economies, which, however, do not have to be centrally planned-a model that seems nowadays hardly justifiable both theoretically and historically. Today, there are also various newer approaches to participatory economy, decentralized and distributed planning, commoning, etc. ${ }^{22}$ Here we will not go into the approaches en détail - what is decisive is only the idea, common to all in different forms, of replacing the non-societal production, which is isolated and then coordinated by the movement of things (flows of goods and money), ${ }^{23}$ with a social production, i.e., ultimately (somehow) communicatively coordinated production. Logically, such production no longer required markets and money, for there would be no exchange (at least not as central economic operation): One (somehow) agrees on what is to be produced, divides (somehow) the work, creates the products, and distributes them according to the initial democratic decisions. Whatever one may think of this concept: It is a social

\footnotetext{
18 This historical exchange derivation of money is probably not tenable (and thus the basis of large parts of today's dominant economics). For details, see, e.g., Kohl (2014).

19 An extremely critical (and therefore naturally controversial) history of capitalism is provided by Kurz (1999), see also Perrault et al. (2001). Especially Kurz also deals with the causes of the external and internal crises of capitalism.

${ }^{20}$ Cf. Heidenreich and Heidenreich (2015), pp. 104-136. See also Heidenreich (2017).

${ }^{21}$ Of course, today, companies try to find out beforehand, for example, through market research, whether the intended products are really needed - interestingly enough, this is already a step towards an ex ante production method.

${ }^{22}$ Cf. Hayek (2007 [1945]) on the fundamental critique of central planning. For a new approach to central planning, see Cockshott and Cottrell (2006). See the debate between Adaman and Devine (2001) and Hodgson (1998, 2005) on participatory and decentralized planning. See Helfrich and Heinrich (2012) on Commons and Commoning. For Commons and 3D printing, see also Nuss (2015)—of course also with reference to Star Trek.

${ }^{23}$ What, incidentally, shows why Bruno Latour's (2010) call for a "Parliament of Things" is so absurd. Things are already governing in capitalism — what Marx (1990), p. 163-177 called the "fetish" — and it would be more important to get people their place again, see Schröter (2011) and Schnödl and Voller (2016), p. 180.
} 
imaginary, the idea of a (supposedly) possible and desirable other social form. ${ }^{24}$ In contrast, a technical imaginary is the idea of a (supposedly) soon possible, worldchanging technology.

(c) Which finally brings us back to 3D printing and the "ideal fabrication machine": In this case, the abolition of capitalist production is conceived quite differently. Here it is not the conversion of the paradoxical, on the one hand individual and on the other hand, indirectly socially mediated mode of production to a directly social mode of production (or a digitally facilitated exchange), but rather the overcoming of exchange (and thus of the market and money) through a still individual, but no longer merely partial, but omnipotent production. What does that mean? Under market conditions, every producer must exchange on the market (and even more so those who can only sell their labor), since it is only possible to produce a certain, small sample of goods individually. But if one had an "ideal manufacturing machine" like the replicator (the question of where it gets its energy from is excluded here), which could really produce anything one wants locally, then one would no longer need to exchange on markets and thus no more money would be necessary — as in Star Trek. Such a machine would, so to speak, leverage capitalism by itself, but without requiring a new communicative form and infrastructure, i.e., a social ex ante organization. Apparently by itself and without the efforts of political enlightenment, discussion, struggle, and even the reshaping of subjectivity, a machine of this kind could overcome the existing form of society. This technical imaginary might be the central reason for the popularity of the 3D print postcapitalism utopia. Thus, Jeremy Rifkin, already quoted, argues that the spread of 3D printing (and other technologies like the "Internet of Things") will inevitably lead to the spread of "collaborative commons" and thus to a substantially peaceful withdrawal of capitalism. $^{25}$

But can it work that way? One can argue against Rifkin that capitalism cannot simply shrink and retreat - that it must constantly expand is one of the most common experiences with this form of production, since the discourse of "growth" is an incessant shrill cry on all channels. ${ }^{26}$ Rather, the spread of technologies that - potentially - shake the very foundations of capitalist production is likely to lead to severe, crisis-like shocks and struggles, as is already being discussed today in connection with digital technologies and the question of the disappearance of (wage) labor, the supposed non-commodity nature of digital products, and their consequences. ${ }^{27}$

Finally, this leads to the interesting question - and already much discussed by Marx in the context of the famous conflict between productive forces and relations of production - whether the social "relations," i.e., the forms and rules of production, for their part do not affect the technologies, i.e., whether a one-sided overcoming of capitalism by a new technology alone (without social changes) is at all possible. The mentioned - potential — non-commodity form of digital goods is a good example: Of course, digital data could in principle be copied without loss: One could, for example,

\footnotetext{
${ }^{24}$ Cf. Castoriadis (1990) as a fundamental attempt on the imaginary constitution of society.

${ }^{25}$ Cf. Rifkin (2014), pp. 7-26.

${ }^{26}$ Cf. already Marx (1990), p. 253.

${ }^{27} \mathrm{Cf}$. Schröter (2019) for an overview of debates on the disappearance of labor; Meretz (2007) on the potential disappearance of the commodity form under the conditions of digital technologies; Lohhoff and Trenkle (2012) on the crisis of capitalism. See also Fischbach (2017) for a well-founded critique of technically based utopias.
} 
simply pass on music files; a practice that many consumers carry out and that deeply shakes a capitalist industry, the music industry. But copying digital data is illegalbecause the commodity form must be maintained and there are technical procedures (e.g., copy protection) which, together with the corresponding legal regulations, serve only the purpose of creating scarcity. ${ }^{28}$

And so, there is another science fiction representation regarding 3D printing, which seems to take this problem into consideration. In 2006, the magazine Nature published a very short story by the well-known American author Cory Doctorow with the beautiful title Printcrime. The story is told by a young woman who remembers at first:

The coppers smashed my father's printer when I was eight. [...] The coppers came through the door with truncheons swinging, one of them reciting the terms of the warrant through a bullhorn. One of Da's customers had shopped him. The ipolice paid in highgrade pharmaceuticals - performance enhancers, memory supplements, metabolic boosters. The kind of things that cost a fortune over the counter; the kind of things you could print at home, if you did not mind the risk of having your kitchen filled with a sudden crush of big, beefy bodies, hard truncheons whistling through the air, smashing anyone and anything that got in the way. [...] Da. What they did to him. When he was done, he looked like he'd been brawling with an entire rugby side. They brought him out the door and let the newsies get a good look at him as they tossed him in the car. All the while a spokesman told the world that my Da's organized-crime bootlegging operation had been responsible for at least 20 million in contraband, and that my Da, the desperate villain, had resisted arrest. [...] By the time I turned 18, they were ready to let Da out of prison. I'd visited him three times - on my tenth birthday, on his fiftieth, and when Ma died. It had been two years since I'd last seen him and he was in bad shape. $^{29}$

The young woman witnessed her father being beaten by some kind of special task force, the flat being demolished, and her father being thrown into prison for 10 years because he had a printer with which to print things that otherwise cost "a fortune over the counter." The father's actions, who caused a loss of "20 million," are considered organized crime. The story is set in a future in which the use of 3D printers (or at least certain private, unregulated forms of use) is radically criminalized. And why is it criminalized? Because it's obviously capable of producing things that would otherwise have to be bought on the market. The father is treated as a terrorist because his use of the $3 \mathrm{D}$ printer undermines capitalist production. This is by no means a completely absurd scenario, given how historically all other new media technologies were subject to a "law of the suppression of radical potential" 30 when they were introduced. At the end of the story, the father is released again - and wants to get himself another 3D printer first. His daughter is horrified:

\footnotetext{
${ }^{28}$ Cf. Senftleben (2010).

${ }^{29}$ Doctorow (2006), p. 242.

${ }^{30}$ Cf. Winston (1998).
} 
I squeezed my hands into fists so tight my fingernails cut into my palms. I closed my eyes. 'You've been in prison for ten years, Da. Ten. Years. You're going to risk another ten years to print out more blenders and pharma, more laptops and designer hats? ${ }^{31}$

This firstly shows that the machine described in the story is obviously more of a replicator à la Star Trek than a modern 3D printer-because no modern additive 3D printer could produce laptops, pharmaceuticals, ${ }^{32}$ and designer hats. But then it becomes clear why the maltreated father absolutely wants to get back to 3D printers: "Lanie, I'm going to print more printers. Lots more printers. One for everyone. That's worth going to jail for. That's worth anything." 33 The father wants to print and distribute 3D printers, because through their mass distribution comes at some point the point at which the technological subversion of the mode of production can no longer be stopped by acts of state violence. The father now sees himself as a martyr of the $3 \mathrm{D}$ print revolution.

With this ending, the narrative assumes that a new technology will ultimately assert itself distributively against the suppression of its radical potential, to quote Winston (1998), and thus negates the necessity of social change (e.g., by changing the laws that permit such acts of police violence and thus decriminalizing 3D printers). The narrative thus also falls short in other respects: if such replicators existed, they would probably not be violently destroyed in capitalism — but would be legally contained by enacting laws that, for example, prohibit the unlicensed production of goods, e.g., by means of protective mechanisms in the replicators that report every printing process somewhere, artificial shortages (e.g., copy protection) of blueprints for objects to be replicated, and much more. Basically, it would probably first be attempted to do it very similarly to what the music industry does today (anyway police force will also be used today, if nothing else helps any more) ${ }^{34}$

Nevertheless, Doctorow's narrative refers to the tension between technology and the social-a tension in which every social change takes place. ${ }^{35}$ Neither can a new technology change society by itself nor can a social change simply adopt the given forms of technology, e.g., because the existing technology itself is shaped by capitalism and the value form. ${ }^{36} \mathrm{~A}$ neo-critical media research will have to keep these coconstitutive, co-evolutionary, but also conflictual processes in mind.

\section{Technical imaginary/social imaginary}

After all, both the replicator and the future associated with him are imaginary. Even the ideas of post-capitalist socialization are (still) imaginary. What is the point of talking about it at all?

\footnotetext{
${ }^{31}$ Doctorow (2006), p. 242.

${ }^{32}$ Which Rifkin (2014) also mentions in his description of the replicator. And in terms of complexity, the coffee machines mentioned by Eversmann (2014) at least come close to the laptops.

${ }^{33}$ Doctorow (2006), p. 242.

${ }^{34}$ See, for example, the events around The Pirate Bay (Wikipedia no year).

35 The question is therefore whether the rejection of the difference between technology and the social in more recent network sociologies, for example, does not invisibilize this tension.

${ }^{36} \mathrm{Cf}$. the question of the capitalist form of technology that emerged in capitalism, Giest (2016).
} 
First of all, the persistence of a pattern such as that of the replicator is conspicuous in purely discourse-analytical terms. Yes, one could even swing up to the steep thesis that the notion of a kind of miracle machine, which, as Rifkin also writes, makes "scarcity" obsolete, is quite old. One reads, for example, in the Bible about the "feeding of the five thousand" from Matthäus 14:

When Jesus heard all this, he took the boat to a lonely place to be alone. But the people in the cities heard about it and went after him on foot. When he got out and saw the many people, he felt sorry for them and healed the sick who were with them. When evening came, the disciples came to him and said, "The place is remote and it is already late. Send the people away so that they can go to the villages and buy something to eat." Jesus replied, "They do not have to go away. Give them food!" They said to him, "We have only five loaves of bread and two fish with us." Then he answered, "Bring them here!" Then he ordered the people to sit on the grass. And he took the five loaves and the two fishes, and looked up to heaven, and said praise, and broke the loaves, and gave them to the disciples; but the disciples gave them to the people, and all ate, and were well-fed. When the disciples collected the remaining pieces of bread, twelve baskets were filled. There were about five thousand men taking part in the meal, women and children as well. ${ }^{37}$

In short: Like a replicator avant la lettre, Jesus produces bread and fish in abundanceone can imagine, what the merchants, who would otherwise have sold the people something to eat, thought of it. Also here the accusation of crime, as in Doctorow's short story, must have been in the air-another reason to crucify Jesus. Of course this is also imaginary, even a "miracle"38; of course one cannot compare the situation over 2000 years ago with modern capitalism - but the imaginary of a once miraculous, now perhaps technically producible, abundance exists. The point is not to ridicule this - on the contrary: This socio-technical imaginary must be defended against the ideologues of supposedly natural scarcity ${ }^{39}$ and the (even Christian) fanatics of laborious work, even if only as a regulative idea of a better, "good" life. The problem today would rather be the point that a technically unlimited abundance, if it were possible, could create completely new ecological problems. $^{40}$

In other words, the above-mentioned options of a different social form of ex ante production and a technical overcoming of exchange by local ultra-abundance would

\footnotetext{
${ }^{37}$ Matthäus 14, 13-21. This scene is much more radical than the often quoted expulsion of the merchants from the temple (Matthäus 21, $12 \mathrm{f}$.) - because there the merchants are only driven away from a certain place and can continue to trade elsewhere, while the food miracle makes the conditions of trade itself (in the sense of buying and selling) obsolete.

38 Dominik Maeder has pointed out to me that a replicator would in a sense be the (phantasmatic) embodiment of the performativity of language: one says "Earl Grey, hot" and the thing appears. This immediately resembles magical conceptions of language, in which the utterance of a magic formula, for example, causes the appearance of a thing — and it naturally resembles the fundamental act of creation: "God said: Let there be light. And it became light." (Genesis 1:3).

39 See critically the alleged nature of "scarcity" Panayotakis $(2011,2012)$.

${ }^{40}$ Cf. Dyer-Witheford (2013).
} 
have to remain related to each other. Once again it becomes apparent that technology and social issues must remain related.

What effect does the imaginary of the "ideal manufacturing machine" (formerly also called "Jesus"), which in some respects is apparently very old, have? That technoimaginary images play a significant role in the development of technology is no longer disputed today. ${ }^{41}$ And as initially quoted from Rifkin, developers like Neil Gershenfeld are explicitly oriented towards the replicator: "The idea, says Gershenfeld, is to provide the tools and materials anyone would need to build whatever they can envision. His ultimate goal 'is to create a Star Trek-style replicator in 20 years.",42

However, it remains to be seen whether it will ever be technologically possible to realize a "molecular synthesizer" such as the replicator from Star Trek. What seems decisive, rather, is that the imaginary of the "ideal manufacturing machine" is a battlefield where negotiations about social forms can be conducted. So the point is not so much that a replicator will really soon be available - and if it were, its developers would certainly soon be hired on Google and Facebook and artificial shortages of blueprints, software, etc. would be set up techno-juridically-but rather to keep asking the questions over and over again what we actually want with a new technology like the $3 \mathrm{D}$ printer. The technological imaginary is the setting for the social imaginary - and vice versa. We must not only be able to imagine radically advanced technologies, but also that the rules and forms of our coexistence, our cooperation, could be different. And both at the same time. This would be the only way to make our imaginary economies perhaps real someday.

And this is at least one part of the answer to the question posed in the exposé for this issue: "How to break through the vicious circle of dissent against capitalism and reinforcement of capitalism's resilience?" First of all, a new imaginary has to be built, one that can imagine the overcoming of capitalism. This is the fundamental operation of every possible change. Strangely enough, fictional scenarios like Star Trek may offer semiotic material to make such alternate imaginary economies at least thinkable: "The world of Star Trek is an economic utopia."43 And the 3D printer/replicator is the ultimate "entanglement of the evolutionary trajectories of energy and calculation" (this is again a quote from the exposé to this issue) - albeit in an imaginary form.

The entanglement between technical and social imaginaries is a complicated matter. On the one hand, technical imaginaries seem to be thinkable more easily - a new wondrous technology changes society by itself, no hard work on communication, institutions, and subjectivity seems to be necessary. But from history, we know on the one hand that this normally does not work-new technologies all too often get subsumed under the prevailing social forms. So it is necessary to develop new social imaginaries too, but these often only emerge by severe crises of the given. But on the other hand, new social imaginaries often get - in lack of a better word - "inspired" by new technological practices. Moving in the networked field of internet communication can connect to the idea of communicative forms of production-why not use new

\footnotetext{
${ }^{41}$ See the already mentioned Leitbild sociology after Dierkes et al. (1992). Cf. recently from the field of Science and Technology Studies Kirby (2010).

${ }^{42}$ Rifkin (2014), p. 79.

${ }^{43}$ Saadia (2016), p. 4. Cf. Davies (2018).
} 
digital communication to extend the field of communicative production ${ }^{44}$ In this way, technical and social imaginaries can reinforce each other - they can coalesce into a more stable and also seemingly reachable imaginary economy (and society) that can act as a "Leitbild" for further political and social struggles.

The existence of such imaginary economies (or at least hints to and parts of such economies) in popular entertainment shows at least that there seems to be an unconscious longing for a kind of change and - given the extreme popularity of Star Trekthis imaginary, moneyless, replicator economy has a planetary impact. The task of analyzing the globally circulating imaginary economies remains an important task for the cultural studies of economy.

Funding Information Open Access funding provided by Projekt DEAL.

Open Access This article is licensed under a Creative Commons Attribution 4.0 International License, which permits use, sharing, adaptation, distribution and reproduction in any medium or format, as long as you give appropriate credit to the original author(s) and the source, provide a link to the Creative Commons licence, and indicate if changes were made. The images or other third party material in this article are included in the article's Creative Commons licence, unless indicated otherwise in a credit line to the material. If material is not included in the article's Creative Commons licence and your intended use is not permitted by statutory regulation or exceeds the permitted use, you will need to obtain permission directly from the copyright holder. To view a copy of this licence, visit http://creativecommons.org/licenses/by/4.0/.

\section{References}

Adaman F, Devine P (2001) Participatory planning as a deliberative democratic process: a response to Hodgson's critique. Econ Soc 30(2):229-239

Castoriadis C (1990) The imaginary institution of society. Polity Press, Malden/MA

Christensen CM, Raynor ME (2003) The innovators solution. Creating and sustaining successful growth. Harvard Business School, Boston/MA

Cockshott, William Paul Cottrell, Allin (2006): Alternativen aus dem Rechner: für sozialistische Planung und direkte Demokratie. Köln: Papyrossa

Davies W (ed) (2018) Economic science fictions. Goldsmiths, London

Dierkes M, Hoffmann U, Marz L (1992) Leitbild und Technik: zur Entstehung und Steuerung technischer Innovationen. Edition Sigma, Berlin

Doctorow C (2006) "Printcrime", in: Nature 439 (2006). http://www.nature.com/nature/journal/v439/n7073 /full/439242a.html (19.03.2017)

Dyer-Witheford N (2013) Red plenty platforms. Cult Mach 14(2013):1-27

Eversmann L (2014) Post-kapitalismus. Blueprint für die nächste Gesellschaft. Heise, Hannover

Fabbri M (2018) The imaginary economy: a new conception. Lfdi, Rome

Fischbach R (2017) Die schöne Utopie. Paul Mason, der Postkapitalismus und der Traum vom grenzenlosen Überfluss. Papyrossa, Köln

Genesis 1 (= 1. Buch Mose 1), 1-31: "Die Erschaffung der Welt", in: Die Bibel. Einheitsübersetzung der Heiligen Schrift (1980). Stuttgart: Katholische Bibelanstalt. https://www.bibleserver.com/text/EU/1. Mose1 (19.03.2017)

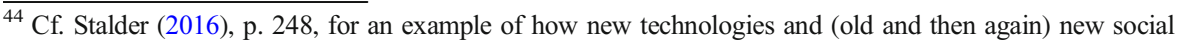
forms co-evolve: "One of the reasons why the very old practice of the commons is now being taken up and widely discussed is that communication-intensive and horizontal processes can be organised much more effectively with digital technologies. Participation and collective organisation beyond small groups need no longer remain mere utopias."
} 
Giest J (2016) Zur Frage nach der "kapitalistischen Technik". Für eine neue Debatte über die reelle Subsumtion der Produktion unter das Kapital. Zeitschrift für Kritische Sozialtheorie und Philosophie 3, 1(2016):26-50

Hayek, Friedrich August von (2007 [1945]) Die Verwertung des Wissens in der Gesellschaft. In Hayek: Wirtschaftstheorie und Wissen. Aufsätze zur Erkenntnis- und Wissenschaftslehre. Publ. by Viktor Vanberg. Tübingen: Mohr Siebeck, pp 57-70

Heidenreich S (2017) Für eine non-monetäre Ökonomie. Merve, Berlin

Heidenreich R, Heidenreich S (2015) Forderungen. Merve, Berlin

Helfrich S, Heinrich Böll S (Hg.) (2012) Commons: Für eine neue Politik jenseits von Staat und Markt. Bielefeld: transcript

Hodgson GM (1998) Socialism against Markets? A Critique of two recent Proposals. Econ Soc 27(4):407433

Hodgson GM (2005) The limits to participatory planning: a reply to Adaman and Devine. Econ Soc 34(1): $141-153$

Hodgson GM (2015) Conceptualizing capitalism: institutions, evolution, future. University of Chicago Press, Chicago

Ingham G (2008) Capitalism. Polity, Cambridge, Malden

Jasanoff S, Kim S-H (2015) Dreamscapes of modernity. Sociotechnical imaginaries and the fabrication of power. Chicago University Press, Chicago and London

Jessop B (2013) Recovered imaginaries, imagined recoveries: a cultural political economy of crisis construals and crisis-management in the North-Atlantic Financial Crisis. In: Benner M (ed) Beyond global economic crisis: economics and politics for a post-crisis settlement. Edward Elgar, Cheltenham, pp 234-254

Kirby D (2010) The future is now: diegetic prototypes and the role of popular films in generating real-world technological development. Social Studies of Science 40(1):41-70

Kohl T (2014) Geld und Gesellschaft. Zur Entstehung, Funktionsweise und Kollaps von monetären Mechanismen, Zivilisation und sozialen Strukturen, Marburg, Metropolis

Kurz R (1999) Schwarzbuch Kapitalismus. Ein Abgesang auf die Marktwirtschaft. Eichborn, Frankfurt a.M.

Latour B (2010) Das Parlament der Dinge. Für eine politische Ökologie. Suhrkamp, Frankfurt a.M.

Lohhoff, Ernst/Trenkle, Norbert (2012): Die große Entwertung. Warum Spekulation und Staatsverschuldung nicht die Ursache der Krise sind. Münster: Unrast

Marx K (1990 [1890]) Capital, Volume 1. London etc.: Penguin

Matthäus 14, 13-21: "Die Speisung der Fünftausend”, in: Die Bibel. Einheitsübersetzung der Heiligen Schrift (1980a). Stuttgart: Katholische Bibelanstalt. https://www.bibleserver.com/text/EU/Matthäus14 (11.03.2017)

Matthäus 21, 12-17: “Die Tempelreinigung”, in: Die Bibel. Einheitsübersetzung der Heiligen Schrift (1980b). Stuttgart: Katholische Bibelanstalt. https:/www.bibleserver.com/text/EU/Matthäus21 (19.03.2017)

McNeil M et al (2017) Conceptualizing imaginaries of science; technology, and society. In: Felt U et al (eds) The handbook of science and technology studies. MIT Press, Cambridge/MA \& London, pp 435-463

Memory Alpha (no year): "Replikator." http://de.memory-alpha.wikia.com/wiki/Replikator (10.03.2017)

Meretz S (2007) Der Kampf um die Warenform. In: Krisis 31. http:/www.krisis.org/2007/der-kampf-um-diewarenform/ (09.01.2017)

Nuss S (2015) Die stigmergische Zukunft. 3D-Drucker in der Küche und eine Welt ohne Geld: über das Potenzial neuer Technologien für die Revolutionierung der Produktionsverhältnisse. In: Neues Deutschland (11.04.2015). https://www.neues-deutschland.de/artikel/967369.die-stigmergische-zukunft. html (03.04.2017)

O’Smith G (1975 [1945]) Pandora’s millions. In: O’Smith: Venus equilateral. Part II. London: Futura, pp 109134

Panayotakis C (2011) Remaking scarcity: from capitalist inefficiency to economic democracy. Pluto Press, London

Panayotakis C (2012) Theorizing scarcity: neoclassical economics and its critics. Rev Radical Political Economics 45(2):S. 183-S. 200

Perrault G et al (2001) Le livre noir du Capitalisme. Le Temps des Cerises, Pantin

Rifkin J (2014) The zero marginal cost society. The internet of things, the collaborative commons and the eclipse of capitalism. Palgrave Macmillan, New York

Saadia M (2016) Trekonomics. The Economics of Star Trek. Pipertext, San Francisco

Schlemm A (2019) Money as an alien: post-monetary elements in utopian literature and science fiction. In: Project Society after Money (ed) Society after money. A dialogue. Bloomsbury, New York, pp 207-226

Schnödl G, Voller C (2016) Von der Herrschaft der Technik zum Parlament der Dinge. Ein Deutungsversuch. Internationales Jahrbuch für Medienphilosophie 2:159-182 
Schröter J (2004) Das Netz und die virtuelle Realität. Zur Selbstprogrammierung der Gesellschaft durch die universelle Maschine. Transcript, Bielefeld

Schröter, Jens (2011): "Das automatische Subjekt. Zu einem Begriff von Karl Marx", in: Hannelore Bublitz/ Irina Kaldrack/Theo Röhle/Hartmut Winkler (Hg.): Unsichtbare Hände. München: Fink, p. 215-256

Schröter, Jens (2019): "Digitale Medientechnologien und das Verschwinden der Arbeit", in: Caja Thimm and Thomas Bächle (eds.): Die Maschine - Freund oder Feind?. Mensch und Technologie im digitalen Zeitakter. Wiesbaden: Springer VS, pp. 183-210

Senftleben M (2010) The answer to the machine revisited. Kopierschutz aus juristischer Sicht. In: Schröter J et al (eds) Kulturen des Kopierschutzes I [= Navigationen 10,1 (2010)]. universi, Siegen, pp 81-93

Stalder F (2016) Kultur der Digitalität. Suhrkamp, Berlin

Star Trek: The Next Generation (US 1988). Paramount Pictures

Star Trek: First Contact (US 1996a). Paramount Pictures

Star Trek (1996b) Jean-Luc Picard über die Wirtschaft der Zukunft. https://www.youtube.com/watch?v= MySHQpkkakQ (10.03.2017)

Sutherland IE (1966) The ultimate display. In: Proceedings of the International Federation of Information Processing Congress 1965. Vol. 2. Washington: Spartan Books und London: Macmillan and Co., pp 506508

Taylor C (2004) Modern social imaginaries. Duke University Press, Durham and London

Wikipedia (no year): “The Pirate Bay.” https://de.wikipedia.org/wiki/The_Pirate_Bay\#Anklage_wegen_ Beihilfe_zur_Verletzung_des_Urheberrechts (19.03.2017)

Winston B (1998) Media, technology and society: a history: from the telegraph to the Internet. Routledge, London/New York

\section{Affiliations}

\section{Jens Schröter ${ }^{1}$}

1 Institut für Sprach-, Medien- und Musikwissenschaft, Abteilung für Medienwissenschaft (Department of Media Studies), Rheinische Friedrich-Wilhelms-Universität Bonn, Lennéstraße 1, 53113 Bonn, Germany 